\title{
Marian Chace Foundation Lecture 2019: Introduction to Nana Koch
}

\section{Elissa Queyquep White ${ }^{1}$}

Published online: 6 May 2020

(c) American Dance Therapy Association 2020

It's truly an honor to be here today to introduce Dr. Nana Koch. We first met in 1980 when Claire Schmais hired Nana to teach in our Dance Therapy Program at Hunter College, City University of New York. Not only were faculty happy, our students spoke (and probably still speak) of Nana's warmth, smile and her all-embracing manner. When Claire retired, Nana stepped into the role of coordinator of the program. It wasn't until then that I got to know Nana better. When Hunter-due to budget cuts-decided to close our program, Nana-to no avail-revealed what a tenacious fighter she is, despite the tragic outcome.

Although I have known Nana for almost 40 years, I did not truly understand the extent of her accomplishments! She has an Ed.D., and two masters degrees, one of which is a Masters of Arts in Elementary Education. In 1971 she received a certificate in Psychomotor Therapy after taking Liljan Espenak's course at New York Medical College/Flower and Fifth Avenue Hospital, and she became a Certified Movement Analyst (CMA) in 1979. She has her NY State LCAT, an LPC, a certification as a Physical Best Instructor, and of course, her BC-DMT. She studied Arts Assessment in Practice for some six years where she learned about theory and practice in program assessment and evaluation. This led her to be an evaluator for The Empire State Partnership Grants, working with groups such as the Elliot Feld's Ballet Tech School, and the New York State Council on the Arts evaluating the Dance Theater of Harlem program in partnership with I.S. 126Q (a public school in New York City). Again, these are just a few examples.

Her academic teaching experiences are long and varied with having taught courses in about seven colleges/universities. Between 1996 when Hunter College's program ended, she taught courses in the Manhattanville College, Department of Dance and Theatre and at Long Island University in the Department of Health, Physical Education and Movement Science. In 2001, she was hired fulltime at Long Island University, became its chair in 2013 and retired from that position this very year.

Elissa Queyquep White

Creeklocks1@gmail.com

1 87-89 Columbia Street, Apartment 16J, New York, NY 10002, USA 
Prior to her academic experiences, Nana worked as a dance/movement therapist from 1971 to 1980 at several institutions including the Association for the Help of Retarded Children, Brooklyn Developmental Center, Pilgrim Psychiatric Center and Fair Oaks Hospital.

Even though Nana's teaching has consisted of courses in group process in dance/movement therapy, the Chace approach to group dance therapy, and movement observation, her passion is Liljan Espenak's Psychomotor Therapy. Fortunately for us, she has taught Espenak's particular approach to clinical work all over the world-Costa Rica, Beijing and Shanghai, Hong Kong, South Korea, Japan, India and Australia.

In the field of health, Nana has conducted workshops such as the "Physical Activity of the Brain - Get up and Move" and "Learn in Motion: An Innovative School Health Promotion Program." She did many more presentations like these, but I just wanted to give you a taste of her work in this field. She is currently a consultant for the Creating Healthy Schools and Communities five-year grant which began in 2015, and which was given to the Rockland County (New York State) Department of Health.

And now for professional activities-for ADTA: committee memberships have included Standards \& Ethics, Educators Council, Approval Committee, and the Subcommittee for the Approval of Alternate Route Courses (SAARC). She was also Chair of Credentials. She has, of course, published many articles ranging from a "Content Analysis of Leadership Variables in Dance Therapy," to interviews of dance/movement therapists, Liljian Espenak and of a joint one of Claire Schmais and me for the American Journal of Dance Therapy to "The 3Rs in Motion: Health, the Body and Learning."

For ADTA (TEDx) Talks, her "Introduction to Dance/Movement Therapy" has been viewed almost 50,000 times via YouTube. For the NYS Chapter of ADTA, she is the interviewer of all the people in their film, "Moving Stories: Portraits of Dance/Movement Therapists." All of this leads up to her most recent activity. She received two grants, one in 2018 and one in 2019 from the Marian Chace Foundation to take eight of the most viewed ADTA Talks on YouTube and had them translated into Chinese, and Spanish, and most recently into Korean and Japanese. This is definitely inspiring.

Last but not least, we come to awards: in 2009, she received the Higher Education Teacher of the Year, awarded by the Nassau Zone of the NYS Association for Health, Physical Education, Recreation and Dance; in 2011, the Amazing Person Award from the Higher Education Professional Preparation Section of the NYS Association for Health, Physical Education, Recreation and Dance; and in 2012, the ADTA awarded her the Excellence in Teaching Award.

Now that Nana has retired, she and her also retired husband, Bob, will be traveling anywhere from four to six months a year, for teaching, pleasure and spending time with their beautiful daughter, Jenna, who lives in Australia. For example, in November she will be presenting at the International Movement Analysis Summit of Creative Arts for Therapy and Education in Beijing. In February 2020 she will teach in Melbourne, Australia. 
In the late 1960s, I was privy, together with Irmgard Bartenieff, Martha Davis and Claire Schmais, to attend a weekly seminar on nonverbal communication. Al Scheflin, an illustrious researcher at the time, informed us that his research showed that when a speaker truly meant what s/he was saying, the right hand would come to the heart. And so, with my right hand on my heart, I am honored to present Dr. Nana Koch, a truly inspiring, talented, accomplished, adventuresome, joyous, and effervescent person who has an inquiring mind and someone who always stands up for what she believes in.

\section{Compliance with Ethical Standards}

Conflict of interest The author declares that she has no conflict of interest.

Ethical Approval This article does not contain any studies with human participants or animals performed by any of the authors.

Publisher's Note Springer Nature remains neutral with regard to jurisdictional claims in published maps and institutional affiliations.

Elissa Queyquep White studied with Marian Chace and Irmgard Bartenieff and co-founded the Dance Therapy Program at Hunter College in 1971. Along with teaching, Elissa worked clinically from 1967 to 1992. She is a charter member of ADTA and served in many capacities on the board of directors, the last being president. She was awarded ADTA's Lifetime Achievement Award in 2010. She teaches courses at Pratt Institute and Kinections, and is on the advisory board for Inspirees Institute for Creative Arts Therapy (IICAT) in Beijing. Elissa has published articles on dance/movement therapy and movement observation. 